\title{
Inorganic pyrophosphatase in uncultivable hemotrophic mycoplasmas: identification and properties of the enzyme from Mycoplasma suis
}

\author{
Katharina Hoelzle*, Simone Peter, Michele Sidler, Manuela M Kramer, Max M Wittenbrink, Kathrin M Felder, \\ Ludwig E Hoelzle
}

\begin{abstract}
Background: Mycoplasma suis belongs to a group of highly specialized hemotrophic bacteria that attach to the surface of host erythrocytes. Hemotrophic mycoplasmas are uncultivable and the genomes are not sequenced so far. Therefore, there is a need for the clarification of essential metabolic pathways which could be crucial barriers for the establishment of an in vitro cultivation system for these veterinary significant bacteria. Inorganic pyrophosphatases (PPase) are important enzymes that catalyze the hydrolysis of inorganic pyrophosphate $\mathrm{PP}_{\mathrm{i}}$ to inorganic phosphate $\mathrm{P}_{\mathrm{i}}$. PPases are essential and ubiquitous metal-dependent enzymes providing a thermodynamic pull for many biosynthetic reactions. Here, we describe the identification, recombinant production and characterization of the soluble (s)PPase of Mycoplasma suis.
\end{abstract}

Results: Screening of genomic M. suis libraries was used to identify a gene encoding the M. suis inorganic pyrophosphatase (sPPase). The M. suis sPPase consists of 164 amino acids with a molecular mass of $20 \mathrm{kDa}$. The highest identity of $63.7 \%$ was found to the M. penetrans sPPase. The typical 13 active site residues as well as the cation binding signature could be also identified in the $M$. suis sPPase. The activity of the M. suis enzyme was strongly dependent on $\mathrm{Mg}^{2+}$ and significantly lower in the presence of $\mathrm{Mn}^{2+}$ and $\mathrm{Zn}^{2+}$. Addition of $\mathrm{Ca}^{2+}$ and EDTA inhibited the $M$. suis sPPase activity. These characteristics confirmed the affiliation of the $M$. suis PPase to family I soluble PPases. The highest activity was determined at $\mathrm{pH}$ 9.0. In M. suis the sPPase builds tetramers of $80 \mathrm{kDa}$ which were detected by convalescent sera from experimentally M. suis infected pigs.

Conclusion: The identification and characterization of the sPPase of M. suis is an additional step towards the clarification of the metabolism of hemotrophic mycoplasmas and, thus, important for the establishment of an in vitro cultivation system. As an antigenic and conserved protein the M. suis sPPase could in future be further analyzed as a diagnostic antigen.

\section{Background}

Mycoplasma suis belongs to a group of highly specialized uncultivable hemotrophic bacteria within the family Mycoplasmataceae that attach to the surface of host erythrocytes $[1,2]$. In the last few years reports on hemotrophic mycoplasmas in various animal species [1] as well as in humans $[3,4]$ continuously increased. Obviously, hemotrophic mycoplasmas are emerging agents with a zoonotic potential. M. suis causes

\footnotetext{
* Correspondence: khoelzle@vetbakt.uzh.ch
Institute of Veterinary Bacteriology, University Zurich, Winterthurerstr. 270

* Correspondence: khoelzle@vetbakt.uzh.ch 8057 Zurich, Switzerland
}

(c) 2010 Hoelzle et al; licensee BioMed Central Ltd. This is an Open Access article distributed under the terms of the Creative Commons Attribution License (http://creativecommons.org/licenses/by/2.0), which permits unrestricted use, distribution, and reproduction in any medium, provided the original work is properly cited. infectious anemia in pigs leading to serious economic loss in the pig industry due to acute anemia as well as chronic persistent infections with increased susceptibility to respiratory and enteric diseases $[1,5]$.

Instead of a clear and long-dated clinical significance of hemotrophic mycoplasmas [6] our knowledge on the physiology and metabolism of hemotrophic mycoplasmas is rather limited. This can primarily led back to their unculturability and the lack of sequence data [6]. Probably, $M$. suis can use glucose as a source of carbon and energy $[7,8]$. However, detailed energy requirements of $M$. suis are largely unknown and its key enzymes have not been described so far. In previous studies we 
successfully screened genome libraries to identify $M$. suis proteins which are involved in pathogenetic processes of $M$. suis infections (e.g. adhesion) and the energy metabolism of these rather unexplored pathogens $[9,10]$. In this paper we identified the soluble inorganic pyrophoshatase (sPPase) of $M$. suis by applying said strategy. Inorganic pyrophosphate $\left(\mathrm{PP}_{\mathrm{i}}\right)$ is an important by-product of many biosynthetic processes, and sPPases which hydrolyze $\mathrm{PP}_{\mathrm{i}}$ to inorganic phosphate $\left(\mathrm{P}_{\mathrm{i}}\right)$, are essential and ubiquitous metal-dependent enzymes providing a thermodynamic pull for many biosynthetic reactions [11-13]. Soluble PPases belong to two nonhomologous families: family I, widespread in all types of organisms [14], and family II, so far confined to a limited number of bacteria and archaea $[15,16]$. The families differ in many functional properties; for example, $\mathrm{Mg}^{2+}$ is the preferred cofactor for family I sPPases studied, whereas $\mathrm{Mn}^{2+}$ confers maximal activity to family II sPPases $[17,18]$. Detailed aims of this study were the recombinant production and characterization of the M. suis sPPase and the comparison of its properties to those of other bacteria. Characterization of essential enzymes in the metabolism of hemotrophic mycoplasmas are important steps towards the establishment of an in vitro cultivation system for this group of hitherto uncultivable hemotrophic bacteria.

\section{Results}

\section{Identification of the $M$. suis inorganic pyrophosphatase} (PPase)

The sPPase of $M$. suis was identified by screening of genomic libraries of $M$. suis using shot gun sequencing. By means of sequence analysis and database alignments of 300 randomly selected library clones we identified library clone $m s 262$ containing an $M$. suis insert with highest identity to the gene encoding the $M$. penetrans sPPase. Since prokaryotic sPPases are known to be essential in energy metabolism $[11,12]$ we selected the $m s 262$ clone for further studies. To confirm the M. suis authenticity of $m s 262$ Southern blot analyses of M. suis genomic DNA were performed using two EcoRI $m s 262$ library fragments as probes. The $m s 262$ EcoRI fragments hybridized with two genomic $M$. suis fragments of 1.2 and $2.7 \mathrm{~kb}$, respectively (Figure 1A). Detailed sequence analysis revealed that the clone $m s 262$ contains a 2059 bp insert with an average $\mathrm{G}+\mathrm{C}$ content of $30.11 \%$. Clone $m s 262$ includes two ORFs (Figure 1B): ORF1 showed the highest identity with $U$. parvum thioredoxin trx (significant BLAST score of $1.3 \times 10^{-7}$, overall sequence identity $44.5 \%)$. ORF2 with a length of 495 bp encodes a 164-aa protein with a calculated molecular mass of 18.6 $\mathrm{kDa}$ and an isoelectric point of 4.72. The ORF2 matched best with $M$. penetrans ppa (63.7\% identity). The overall degrees of identity to the ppa of $U$. urealyticum,

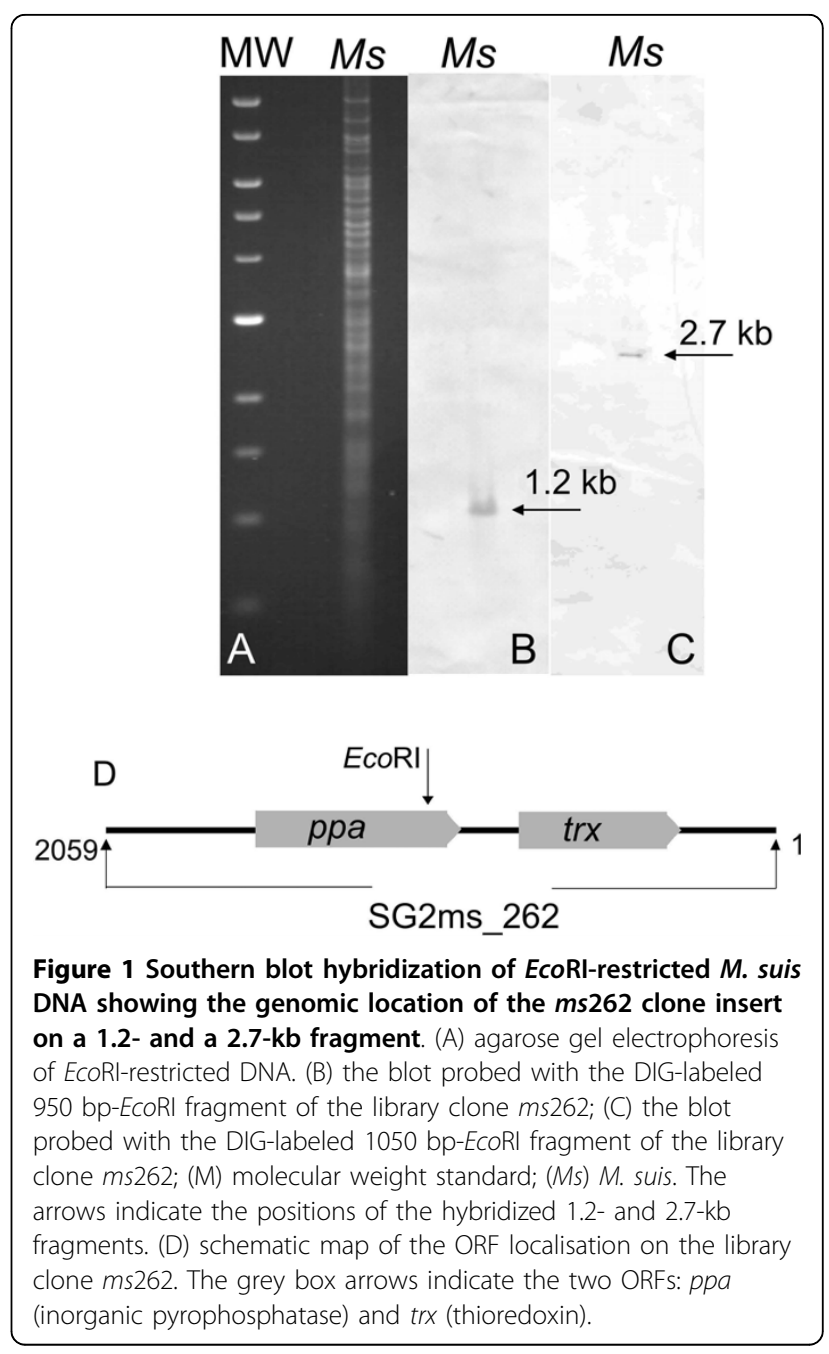

M. mycoides ssp mycoides, and M. capricolum ssp capricolum were calculated to be $59.7 \%, 58.7 \%$, and $58.3 \%$, respectively. Figure 2 shows an alignment of sPPases of selected Mycoplasma species. The characteristic signature of sPPase which is essential for the binding of cations was identified at amino acid positions 54 to 60 (Figure 2) using the program PREDICT PROTEIN http://cubic.bioc.columbia.edu/predictprotein/. Possible signatures for sPPases are $\underline{\mathrm{D}}[\mathrm{SGDN}] \underline{\mathrm{D}}[\underline{\mathrm{PE}}][\underline{\mathrm{L} I V M F} \underline{\mathrm{D}}$ [LIVMGAG]. The signature of the $M$. suis sPPase was determined as DGDPLDV (amino acids are underlined in the universal signature; Figure 2). The 13 conserved residues which build the active site of sPPases could be identified in the M. suis sPPase, too (Figure 2).

\section{Expression of recombinant PPase in E. coli}

The entire ORF of the $M$. suis ppa was assembled as a synthetic gene and one $\mathrm{UGA}_{\text {Trp }}$ codon at position 274276 was replaced by UGG. Other changes in the synthetic ppa were done to optimize the sequence for the 


\begin{tabular}{|c|c|}
\hline M. mycoides & 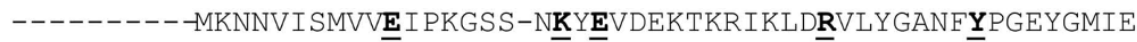 \\
\hline M. capricolum & 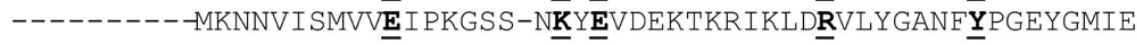 \\
\hline M. suis & $-------M S K N N I V E C F I \underline{\mathbf{E}} I A K H S N-L \underline{\mathbf{K}} Y \underline{\underline{\mathbf{E}}}$ CVDG--KLKLD $\underline{\mathbf{R}} V L F G S M V \underline{\mathbf{Y}}$ PHNYGYIS \\
\hline M. genit & $--------M D K F L I D V I V \underline{\overline{\mathbf{E}}} I P K N S K-I \underline{\overline{\mathbf{K}}} Y \underline{\overline{\mathbf{E}}} Y$ DRQTGQIRVD疋ILFGSES $\underline{\overline{\mathbf{Y}}} \mathrm{PQNYGFIK}$ \\
\hline M. pneumoniae & 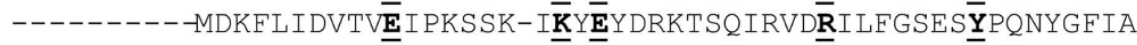 \\
\hline M. penetrans & 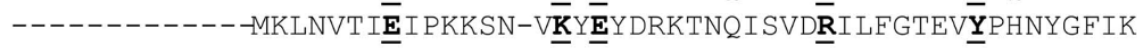 \\
\hline U. urealyticum & 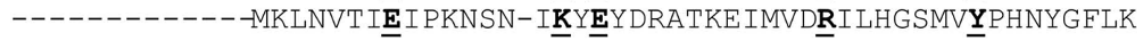 \\
\hline M. gallisepticum & 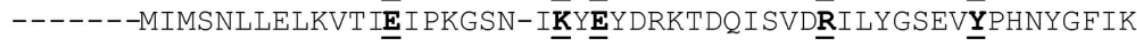 \\
\hline M. hyopneumoniae & ENKIILVDIE ISKGSN-I $\underline{\overline{\mathbf{K}}}$ Y $\underline{\mathbf{E}} L D S K T K K L V V D \underline{\mathbf{R}} I L Y G D F V \underline{\mathbf{Y}}$ PANYGSIP \\
\hline E. Coli & 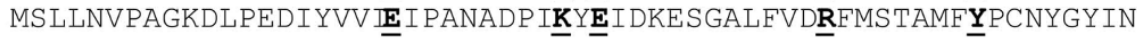 \\
\hline
\end{tabular}

M. mycoides

M. capricolum

M. suis

M. genitalium

M. pneumoniae

M. penetrans

U. urealyticum

M. gallisepticum

M. hyopneumoniae

E. COli

$$
\begin{aligned}
& \text { M. mycoides } \\
& \text { M. capricolum } \\
& \text { M. suis } \\
& \text { M. genitalium } \\
& \text { M. pneumoniae } \\
& \text { M. penetrans } \\
& \text { U. urealyticum } \\
& \text { M. gallisepticum } \\
& \text { M. hyopneumoniae } \\
& \text { E. Coli }
\end{aligned}
$$

Figure 2 Alignment of the sPPase sequences of M. suis, selected Mycoplasma species and Escherichia coli. Sequences were aligned using the ClustalW tool http://www.ebi.ac.uk/Tools/clustalw2/. The 13 conserved residues which build the active site (Sivula et al., 1999) are bold-faced and underlined. The residues which are essential for the cation binding are emphasized by a grey box. Accession numbers for the sequences follow: M. mycoides ssp mycoides SC str. PG1 NC_005364; M. capricolum ssp capricolum CP000123; M. suis FN394679; M. genitalium L43967; M. pneumoniae U00089; M. penetrans NC_004432; U. urealyticum serovar 10 NC_011374; M. gallisepticum AE015450; M. hyopneumoniae NC_007295; E. coli NC_010468.

heterologous E. coli expression. Induction of E. coli transformants containing the ppa gene resulted in the high-level expression of a $20 \mathrm{kDa}$-protein as shown in Figure 3A. Recombinant PPase was used to raise a PPase-specific rabbit polyclonal antiserum. The specificity of the rabbit serum was demonstrated by probing an immunoblot containing purified rPPase and a $M$. suis preparation. The anti-PPase serum reacted clearly with a single band of $20 \mathrm{kDa}$ corresponding to the purified rPPase. In the $M$. suis preparations a weak band of $20 \mathrm{kDa}$ and a clear band of $80 \mathrm{kDa}$ potentially corresponding to a tetrameric form of the $M$. suis PPase were detected (Figure 3B). No reaction could be observed neither with the blood control preparation of M. suis negative pigs nor the non-induced $E$. coli control.

\section{Characterization of PPase in $M$. suis}

In order to prove the conserved existence of the PPase gene in M. suis, 25 M. suis isolates (20 isolates from domestic pigs and five isolates from wild boars) were screened by PCR. All isolates revealed a PCR amplification product of the expected size of approximately $500 \mathrm{bp}$. Sequence analysis of ten ppa PCR products revealed $100 \%$ sequence identity with the determined $M$. suis ppa sequence (Accession number FN394679).

To determine the antigenicity of the PPase of M. suis we analyzed convalescent serum pools from experimentally infected pigs by immunoblotting. All convalescent serum pools reacted clearly with rPPase. No reaction could be observed with sera taken from $M$. suis negative pigs. A representative immunoblot is shown in Figure 3C. 


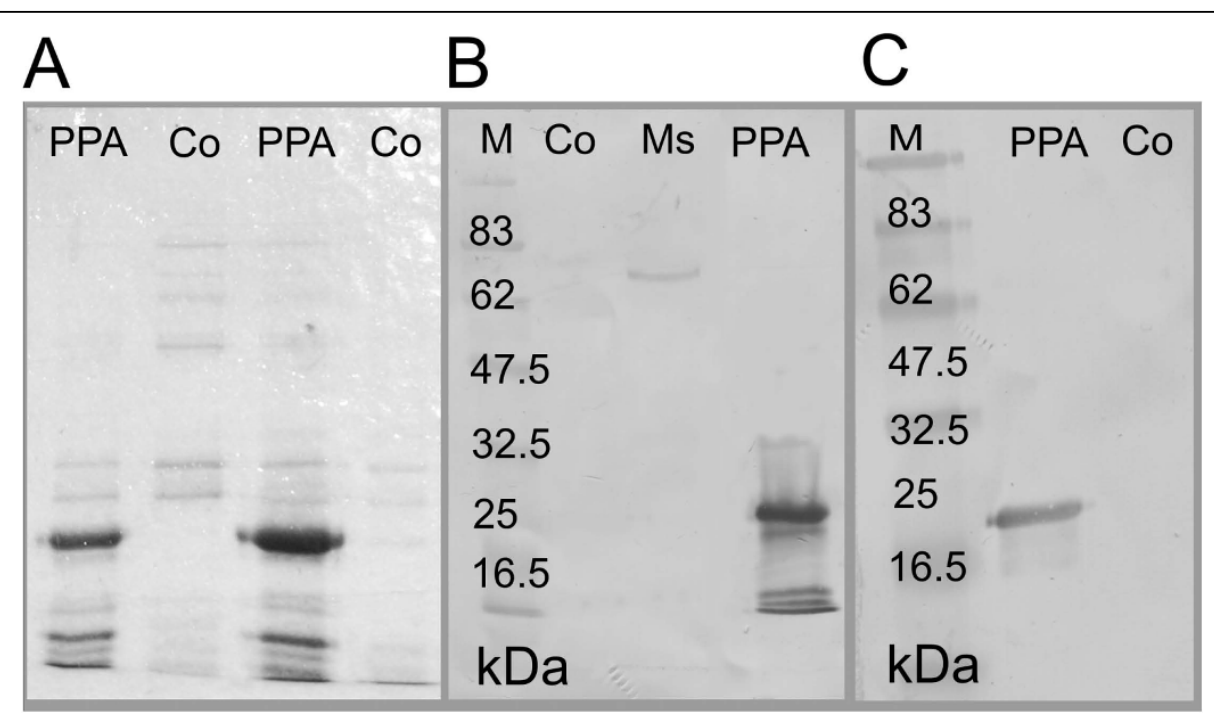

Figure 3 Expression and immunological characterization of the $\boldsymbol{M}$. suis sPPase. (A) Coomassie-stained SDS polyacrylamide gel electrophoresis of recombinant M. suis PPase., Co, non-induced IMAC purified E. coli lysate; PPA, IMAC purified recombinant PPase. (B) Immunoblot analysis of recombinant PPase and $M$. suis whole cell antigen; immunological detection with anti-PPase rabbit immune serum; $M$, molecular weight standard; PPA, recombinant PPase; Ms, purified M. suis cells; Co, non-induced IMAC purified E. coli lysate. (C) Immunoblot of recombinant PPAse; immunological detection with a serum pool from experimentally infected pigs; PPA, recombinant PPase; Co, non-induced IMAC purified E. coli lysate.

\section{Functional characterization of recombinant $M$. suis PPase}

The dependency of the $M$. suis PPase activity on the $\mathrm{pH}$ value was determined between $\mathrm{pH} 5$ and 10.5. As shown in Figure 4D the optimum $\mathrm{pH}$ for the $M$. suis PPase activity was observed at $\mathrm{pH}$ 9.0. At conditions below pH 7.5 and above $\mathrm{pH} 10.0$ its activity decreased considerably.

The effect of different $\mathrm{Mg}^{2+}$ concentrations on the M. suis PPase activity is shown in Figure 4A. High enzyme activity was found between 1 and $100 \mathrm{mM} \mathrm{Mg}^{2+}$ with a maximum activity at a concentration of $10 \mathrm{mM}$ $\mathrm{Mg}^{2+}$. Performing the reaction at a $\mathrm{pH}$ of 7.5 the maximum PPase activity was found at a concentration of $50 \mathrm{mM}$. Using an $\mathrm{Mg}^{2+}$ depleted reaction buffer the $M$. suis PPase-mediated PPi hydrolysis was nearly abolished. Substitution of $\mathrm{Mg}^{2+}$ cations with $\mathrm{Mn}^{2+}$ and $\mathrm{Zn}^{2+}$ resulted in significantly lower activities of $25.34 \% \pm$ $12.1 \%$, and $14.3 \% \pm 9.5 \%$ respectively of the $\mathrm{Mg}^{2+}$ induced activity (Figure 4B).

To further characterize the $M$. suis PPase the effect of inhibitors on the activity was evaluated. Enzymatic activity was inhibited more than $95 \%$, and $70 \%$ in the presence of $5 \mathrm{mM} \mathrm{Ca}^{2+}$ and $5 \mathrm{mM}$ EDTA, respectively (Figure 4C).

\section{Discussion}

In this study, we identified, for the first time, a gene encoding the sPPase of one representative of the uncultivable hemotrophic mycoplasma group, i.e. M. suis. PPase plays an important role in the bacterial energy metabolism [11,12] and is the enzyme responsible for the hydrolysis of pyrophosphate which is formed principally as the product of many biosynthetic reactions that utilize ATP. Since our knowledge on the metabolism of $M$. suis and other hemotrophic mycoplasmas is rather limited enzymes associated with their metabolism are of our special interest.

The $M$. suis ORF encoding the sPPase showed a typically low $\mathrm{G}+\mathrm{C}$ content of $30.11 \%$ which lies within the normal range of other mycoplasmas $[19,20]$. The identified $M$. suis sPPase signature sequence which is responsible for the cation binding was identical to those of $M$. mycoides ssp mycoides and $M$. capricolum ssp capricolum. Furthermore, all functionally important active site residues could be identified in the M. suis sPPase. Interestingly, the $M$. suis sPPase is considerably shorter than other mycoplasma sPPases (164 vs. 180-185 amino acid residues) due to differences in the $\mathrm{C}$-terminal region. State-of-the-art knowledge on the uncultivable hemotrophic mycoplasmas does not allow for a statement as to which function the absence of amino acid residues on the $\mathrm{C}$-terminus might incur. There could be a possible relevance for its subcellular localization. Additionally, the $m s 262$ clone harbors a second ORF encoding a putative $M$. suis thioredoxin. The thioredoxin system operates via redox-active disulphides and provides electrons for a wide range of metabolic processes in prokaryotic cells. Especially within the genus Mycoplasma the thioredoxin complex apparently belongs to the metabolic core reactions [21,22]. Comparison of the 

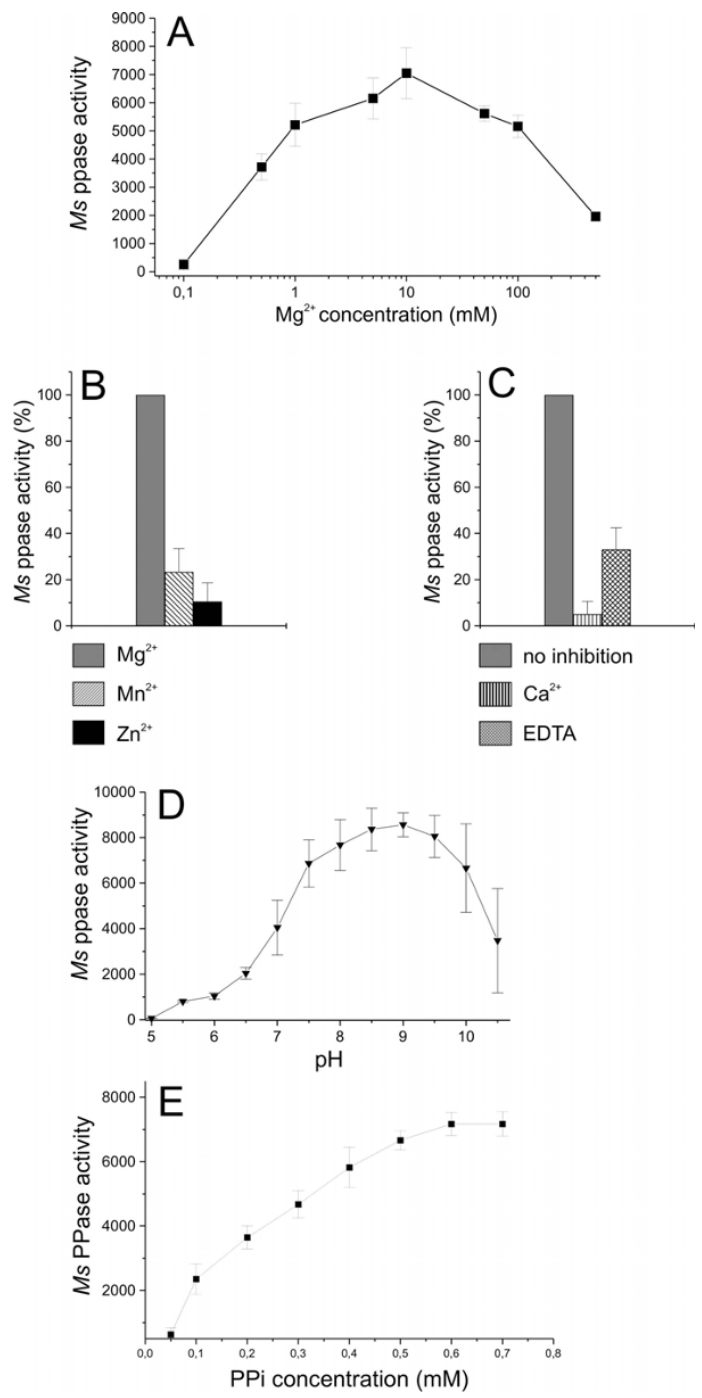

Figure 4 Functional characterization of the recombinant M. suis sPPase. (A) Activation of $M$. suis rPPase by $\mathrm{Mg}^{2+}$. The rPPase $(10 \mathrm{ng} / \mathrm{\mu l})$ was incubated for $5 \mathrm{~min}$ in the same buffer containing different concentrations of $\mathrm{MgCl}_{2}$. Values represent mean values \pm standard deviation of five independent experiments. (B) Differences in the activation of rPPase by $\mathrm{Mg}^{2+}, \mathrm{Mn}^{2+}$, or $\mathrm{Zn}^{2+}$. Recombinant PPase $(10 \mathrm{ng} / \mu \mathrm{l})$ was incubated for $5 \mathrm{~min}$ in the same buffer containing $5 \mathrm{mM} \mathrm{MgCl}_{2}, 5 \mathrm{mM} \mathrm{MnCl}_{2}$ and $5 \mathrm{mM} \mathrm{MgCl}_{2}$,

respectively. Activation of $\mathrm{M}$. suis rPPase by $\mathrm{MgCl}_{2}$ was set as $100 \%$. Values represent mean values \pm standard deviation of triplicates. (C) Inhibition of $\mathrm{M}$. suis rPPase activity by $\mathrm{Ca}^{2+}$ and EDTA. Recombinant PPase $(10 \mathrm{ng} / \mu \mathrm{l})$ was incubated for $5 \mathrm{~min}$ in buffer containing $5 \mathrm{mM} \mathrm{MgCl}_{2}$ alone and with $5 \mathrm{mM} \mathrm{CaCl}_{2}$ and $5 \mathrm{mM}$ EDTA, respectively. Activity value of $\mathrm{M}$. suis $\mathrm{rPPase}$ with $\mathrm{MgCl}_{2}$ alone was set as $100 \%$. Values represent mean values \pm standard deviation of triplicates. (D) pH value dependency of the M. suis rPPase activity. PPase activity was measured using $50 \mathrm{mM} \mathrm{MgCl}$ and buffers with increasing $\mathrm{pH}$ values. Data represent mean values \pm standard deviation from five independent experiments. (E) Activity of M. suis rPPase using different PPi concentrations. Activity was measured with fixed concentrations of rPPase $(10 \mathrm{ng} / \mathrm{\mu l})$ and $50 \mathrm{mM} \mathrm{MgCl}_{2}$ at a $\mathrm{pH}$ of 9.0. Values represent mean values \pm standard deviation of five independent experiments. genome structures flanking the $p p a$ ORF with the sequenced Mycoplasma species revealed no homologies (data not shown).

After heterologous expression of the sPPase in E. coli the protein was found in the cytoplasm with a molecular weight of $20 \mathrm{kDa}$. In $M$. suis whole cell preparations the sPPase was detected as a $20 \mathrm{kDa}$ band to a minor degree. Predominantly the enzyme was found to have a molecular weight of approx. $80 \mathrm{kDa}$ indicating that the $M$. suis sPPase obviously consists of four subunits. Since the inference that the $M$. suis sPPase is tetrameric is solely based on the results of an immunoblot using antirPPase antibodies (Fig 3B) the final proof of the tetrameric form has to be provided as soon as an in vitro cultivation of $M$. suis is possible. For other Mycoplasmas nothing is known about the protein properties of sPPase since they have only been identified via their DNA sequences. However, other studies report that most eubacterial PPases are homohexamers [23,24], and, as is unusual, sometimes homotetramers e.g. Aquifex aeolicus [25,26] or Rhodospirillum rubrum [27]. Where molecular phylogeny is concerned the Mycoplasma sPPases are clustered with the cyanobacteria within the prokaryotic Family I PPase lineage [27]. The M. suis sPPase showed characteristic properties in terms of cation requirement: $\mathrm{Mg}^{2+}$ confers the highest efficiency in activating the $M$. suis sPPase in a concentration-dependent manner. Other cations $\left(\mathrm{Zn}^{2+}\right.$ and $\left.\mathrm{Mn}^{2+}\right)$ could replace $\mathrm{Mg}^{2+}$, but the effectiveness of the latter cations was significantly lower. Furthermore, $\mathrm{Ca}^{2+}$ and EDTA inhibited the enzyme for catalysis. These results support the conclusion that the M.suis sPPase belongs to the Family I PPases. Family I PPase has shown strong metal cationdependency, with $\mathrm{Mg}^{2+}$ conferring the highest efficiency [14] and sensitivity to inhibition by $\mathrm{Ca}^{2+}$ [28]. In contrast, Family II PPase prefers $\mathrm{Mn}^{2+}$ over $\mathrm{Mg}^{2+}$ [17]. The most notable characteristic of the $M$. suis recombinant sPPase was its $\mathrm{pH}$ activity profile with an optimum at $\mathrm{pH} 9.0$ since (i) optimal $\mathrm{pH}$ of most bacterial sPPases ranged from $\mathrm{pH} 5.0$ to 8.0 [25], and (ii) the physiological blood $\mathrm{pH}$ value of pigs is $7.4 \pm 0.4$. Therefore, it is ambiguous which role the unusual $\mathrm{pH}$ optimum could play with regard to the pathogenesis of $M$. suis induced diseases. Moreover, no statement is possible about optimal $\mathrm{pH}$ ranges for other mycoplasmal sPPases since this study is the first functional characterization of a sPPase of a Mycoplasma species. For M. suis it is known that experimental induced acute diseases lead to severe hypoglycemia and blood acidosis with a mean $\mathrm{pH}$ value of 7.13 [29]. All these changes were considered to result from the high glucose consumption of $M$. suis during maximum bacteremia [1]. However, nothing is known about the changes in blood parameters during natural $M$. suis infections and especially during the chronic 
course of persistent infections with nearly physiological glucose metabolism. It has been reported from other infections, e.g. Streptococcus pneumoniae-infections in rats that infections could lead to significantly increased blood $\mathrm{pH}$ values [30].

Notably, infected pigs showed antibodies against recombinant sPPase. This may result from the sPPase being an ectoenzyme which might be located on the external surface. Alternatively, anti-Ms PPAse antibodies could be an outcome of bacterial lysis in the animal host. The first possibility is rather unlikely since no signal peptide was found in any Mycoplasma PPase and all other Familiy I PPases are clearly soluble and not secreted [27]. Probably sPPase could be one of the eight $M$. suis specific antigens which we have described recently [9].

\section{Conclusion}

By using a screening of genomic libraries of uncultivable bacteria $M$. suis we were able to identify so far unknown components of the energy metabolism. We identified and characterized the inorganic pyrophosphatase of M. suis. Knowing the functional characteristics of such an essential enzyme may help to establish an in vitro cultivation system for hemotrophic mycoplasmas. Furthermore, as an antigenic and conserved protein $M$. suis sPPase could in future be further analyzed as a diagnostic antigen.

\section{Methods}

Bacterial strains and isolates, plasmids, and experimental porcine sera

M. suis cells were obtained from experimentally infected pigs as previously described [31,32]. E. coli K12 strains were Top10 and LMG194 (Invitrogen, Basel, Switzerland). For DNA manipulation and protein expression the plasmids pUC19 (Roche-Diagnostics, Rotkreuz, Switzerland) and $\mathrm{pBad} M y c H i s$ (C-terminal His- and $M y c$-tag, Invitrogen) were used. Experimental sera and $M$. suis isolates were available from previous studies $[33,34]$.

\section{DNA extraction, library construction and sequence analysis}

DNA extraction of $M$. suis was performed as previously described [31]. Customized DNA library construction was performed by Medigenomix (Martinsried, Germany). M. suis DNA fragments averaging from $1.5 \mathrm{~kb}$ to $3.0 \mathrm{~kb}$ were ligated into the pUC19 vector. In order to detect $M$. suis sequences 300 clones were randomly selected for DNA-sequencing. Customized sequencing was performed by Medigenomix. Nucleotide sequences were analyzed by using the FASTA aligorithm (Biocomputing service, University Zurich, http://www.bio.unizh. ch. For determination of putative open reading frames we used an ORF finder program http://www.ncbi.nlm. nih.gov/projects/gorf/. Translation of ORFs to amino acid sequences was performed by taking into account the alternative genetic codon usage of mollicutes (UGA encodes tryptophan instead of stop).

\section{Hybridization analysis}

Hybridization was performed as previously described [31]. Briefly, M. suis genomic DNA was digested with EcoRI, analyzed on a $0.8 \%$ agarose gel and transferred to Hybond- $\mathrm{N}$ nylon membranes by capillary transfer using $1.5 \mathrm{M} \mathrm{NaCl}, 0.25 \mathrm{M} \mathrm{NaOH}$ as transfer buffer. The ppacontaining library clone $m s 262$ was digested with the restriction enzymes HindIII and EcoRI. Due to an internal EcoRI digestion site the insert was divided into two fragments of approx. $1200 \mathrm{bp}$ and $800 \mathrm{bp}$. Both fragments were labeled with digoxigenin-dUTP (RocheDiagnostics) and used as probes.

\section{Cloning, expression of $M$. suis $p p a$ and purification of the recombinant enzyme}

To account for the Mycoplasma specific use of the UGA codon as tryptophan the ppa sequence was adapted to the codon usage of $E$. coli and de novo synthesized (Medigenomix). The de novo ppa was ligated into the $\mathrm{pBad} M y c \mathrm{His}$ vector ( $\mathrm{pBad}-p p a)$ and transformed into E. coli LMG194.

Recombinant pBad-ppa E. coli clones were grown to an $\mathrm{OD}_{600 \mathrm{~nm}}$ of 0.6 at $37^{\circ} \mathrm{C}$. Protein expression was induced by the addition of $0.02 \%$ arabinose. E. coli cultures were further incubated for $2 \mathrm{~h}$ at $37^{\circ} \mathrm{C}$. His-tagged proteins were purified by nickel affinity chromatography (Qiagen, Hombrechtikon, Switzerland) as previously described $[9,10]$. The purification of 2 liter culture yielded a total of $1 \mathrm{mg}$ recombinant protein. Purity of protein was estimated as $90 \%$. Non-induced cultures were prepared accordingly as controls for immunoblots and enzyme activity assays.

\section{Enzyme activity assay}

Protein content was determined by the method of Bradford (BioRad, Reinach, Switzerland) using bovine serum albumin as a standard. The recombinant $M$. suis sPPase activity was assayed as described by Saheki and coworkers [35] using a reaction mixture containing $5 \mathrm{mM}$ $\mathrm{Mg}^{2+}, 100 \mathrm{mM}$ Tris, $\mathrm{pH} 7.5$ and $1 \mathrm{mM} \mathrm{PP} \mathrm{i}_{4}\left(\mathrm{Na}_{4} \mathrm{P}_{2} \mathrm{O}_{7}\right)$ at $55^{\circ} \mathrm{C}$ in a final volume of $200 \mu \mathrm{l}$. Reactions were started by adding $10 \mu \mathrm{L}$ diluted $M$. suis rPPase (100 ng) and stopped by adding $1 \mathrm{ml} 200 \mathrm{mM}$ Glycin/HCl, pH 3.0. Then, $125 \mu \mathrm{l}$ of $1 \%$ ammonium molybdate (in $25 \mathrm{mM}$ $\mathrm{H}_{2} \mathrm{SO}_{4}$ ) and $125 \mu \mathrm{l}$ of $1 \%$ ascorbic acid (in $0.05 \% \mathrm{KHSO}_{4}$ ) were added to the mixtures and incubated for $30 \mathrm{~min}$ at $37^{\circ} \mathrm{C}$. Yeast sPPase (Sigma, Buchs, Switzerland) was used as positive control. Preparations derived from non-induced pBad-ppa (purified accordingly to recombinant PPase) were used as negative controls. To determine the $\mathrm{Mg}^{2+}$ 
and $\mathrm{pH}$ dependency individual assay components were varied. Activity was also measured using $5 \mathrm{mM} \mathrm{Mn}^{2+}, \mathrm{Zn}^{2+}$ instead of $\mathrm{Mg}^{2+}$ cations. For inhibition assays $5 \mathrm{mM} \mathrm{Ca}^{2+}$ and EDTA, respectively, were added to the reaction mixture. The amount of $\mathrm{P}_{\mathrm{i}}$ liberated from the hydrolysis of $\mathrm{PP}_{\mathrm{i}}$ was measured using a spectrophotometer (Shimadzu 160UV-A) and a standard $P_{i}$ curve. The PPase activity was defined as $\mu \mathrm{mol} \mathrm{P}_{\mathrm{i}} \mathrm{min}^{-1} \mathrm{mg}^{-1}$ protein.

\section{Preparation of an anti-PPase rabbit immune serum}

A rabbit immune serum was prepared as previously described [10] using $0.4 \mathrm{mg}$ recombinant PPase for each immunization. Immunizations were conducted under the registration number 156/2002 with the legal prescriptions.

\section{SDS PAGE and immunoblots}

SDS PAGE and immunoblots were performed according to standard protocols. The M. suis cells were prepared from the blood of experimentally infected pigs as previously described [32]. Negative controls were accordingly prepared from the blood of M. suisnegative pigs.

\section{PCR and sequencing}

PCR amplification of the $p p a$ gene was performed using the primers: $p p a \_f o r:$ ATGTCAAAAAATAATATAGTGGA; ppa_rev TTAATAATTTGATTGTTATTCTCC, and the HotStarTaq Polymerase Master Mix (Qiagen). PCR conditions were: $15 \mathrm{~min}$ at $95^{\circ} \mathrm{C}$ for activation of Taq polymerase, 30 cycles of denaturation at $95^{\circ} \mathrm{C}$ for $30 \mathrm{~s}$, annealing at $60^{\circ} \mathrm{C}$ for $30 \mathrm{~s}$, and extension at $72^{\circ} \mathrm{C}$ for $1 \mathrm{~min}$. Amplified fragments were purified using the Qiaquick PCR Purification Kit (Qiagen) and sequenced (Medigenomix).

The ppa sequence was deposited in the EMBL Nucleotide Sequence Database under accession number FN394679.

\begin{abstract}
Authors' contributions
$\mathrm{KH}$-planned, developed and co-coordinated the project, analyzed the data, wrote the manuscript; SP-functional characterization; did the enzyme activity assays; MS-screened the $M$. suis genomic libraries, performed the hybridization experiments; MK-expressed the inorganic pyrophosphate in $E$. coli, performed SDS PAGE and immunoblots; MMW-contributed to the data analysis and manuscript preparation; KMF-performed enzyme activity assays, protein purification procedures, SDS PAGE and immunoblots; LEH-project design, manuscript preparation and project oversight.
\end{abstract}

Received: 27 October 2009 Accepted: 20 July 2010 Published: 20 July 2010

\section{References}

1. Hoelzle LE: Haemotrophic mycoplasmas: recent advances in Mycoplasma suis. Vet Microbiol 2008, 130:215-226.

2. Zachary JF, Basgall EJ: Erythrocyte membrane alterations associated with the attachment and replication of Eperythrozoon suis: a light and electron microscopic study. Vet Pathol 1985, 22:164-170.

3. Hu Z, Yin J, Shen K, Kang W, Chen Q: Outbreaks of hemotrophic mycoplasma infections in China. Emerg Infect Dis 2009, 15:1139-1140.
4. dos Santos AP, dos Santos RP, Biondo AW, Dora JM, Goldani LZ, de Oliveira ST, de Sa Guimaraes AM, Timenetsky J, de Morais HA, Gonzalez FH, Messick JB: Hemoplasma infection in HIV-positive patient, Brazil. Emerg Infect Dis 2008, 14:1922-1924.

5. Messick JB: Hemotrophic mycoplasmas (hemoplasmas): a review and new insights into pathogenic potential. Vet Clin Pathol 2004, 33:2-13.

6. Neimark H, Johansson KE, Rikihisa Y, Tully JG: Proposal to transfer some members of the genera Haemobartonella and Eperythrozoon to the genus Mycoplasma with descriptions of 'Candidatus Mycoplasma haemofelis', 'Candidatus Mycoplasma haemomuris', 'Candidatus Mycoplasma haemosuis' and 'Candidatus Mycoplasma wenyonii'. Int J Syst Evol Microbiol 2001, 51:891-899.

7. Nonaka N, Thacker BJ, Schillhorn van Veen TW, Bull RW: In vitro maintenance of Eperythrozoon suis. Vet Parasitol 1996, 61:181-199.

8. Smith JE, Cipriano JE, Hall SM: In vitro and in vivo glucose consumption in swine eperythrozoonosis. Zentralb/ Veterinarmed B 1990, 37:587-592.

9. Hoelzle LE, Hoelzle K, Harder A, Ritzmann M, Aupperle H, Schoon HA, Heinritzi K, Wittenbrink MM: First identification and functional characterization of an immunogenic protein in unculturable haemotrophic Mycoplasmas (Mycoplasma suis HspA1). FEMS Immunol Med Microbiol 2007, 49:215-223.

10. Hoelzle LE, Hoelzle K, Helbling M, Aupperle H, Schoon HA, Ritzmann M, Heinritzi K, Felder KM, Wittenbrink MM: MSG1, a surface-localised protein of Mycoplasma suis is involved in the adhesion to erythrocytes. Microbes Infect 2007, 9:466-474.

11. Chen J, Brevet A, Fromant M, Leveque F, Schmitter JM, Blanquet S, Plateau P: Pyrophosphatase is essential for growth of Escherichia coli. J Bacteriol 1990, 172:5686-5689.

12. Lundin M, Baltscheffsky $H$, Ronne $H$ : Yeast PPA2 gene encodes a mitochondrial inorganic pyrophosphatase that is essential for mitochondrial function. J Biol Chem 1991, 266:12168-12172.

13. Sonnewald U: Expression of E. coli inorganic pyrophosphatase in transgenic plants alters photoassimilate partitioning. Plant J 1992, 2:571-581.

14. Cooperman BS, Baykov AA, Lahti R: Evolutionary conservation of the active site of soluble inorganic pyrophosphatase. Trends Biochem $\mathrm{SCl}$ 1992, 17:262-266.

15. Shintani T, Uchiumi T, Yonezawa T, Salminen A, Baykov AA, Lahti R, Hachimori A: Cloning and expression of a unique inorganic pyrophosphatase from Bacillus subtilis: evidence for a new family of enzymes. FEBS Lett 1998, 439:263-266.

16. Young TW, Kuhn NJ, Wadeson A, Ward S, Burges D, Cooke GD: Bacillus subtilis ORF yybQ encodes a manganese-dependent inorganic pyrophosphatase with distinctive properties: the first of a new class of soluble pyrophosphatase? Microbiology 1998, 144(Pt 9):2563-2571.

17. Parfenyev AN, Salminen A, Halonen P, Hachimori A, Baykov AA, Lahti R: Quaternary structure and metal ion requirement of family II pyrophosphatases from Bacillus subtilis, Streptococcus gordonii, and Streptococcus mutans. J Biol Chem 2001, 276:24511-24518.

18. Zyryanov AB, Vener AV, Salminen A, Goldman A, Lahti R, Baykov AA: Rates of elementary catalytic steps for different metal forms of the family ॥ pyrophosphatase from Streptococcus gordonii. Biochemistry 2004, 43:1065-1074.

19. Chambaud I, Heilig R, Ferris S, Barbe V, Samson D, Galisson F, Moszer I, Dybvig K, Wroblewski H, Viari A, et al: The complete genome sequence of the murine respiratory pathogen Mycoplasma pulmonis. Nucleic Acids Res 2001, 29:2145-2153.

20. Himmelreich R, Hilbert H, Plagens H, Pirkl E, Li BC, Herrmann R: Complete sequence analysis of the genome of the bacterium Mycoplasma pneumoniae. Nucleic Acids Res 1996, 24:4420-4449.

21. Pollack JD, Williams MV, McElhaney RN: The comparative metabolism of the mollicutes (Mycoplasmas): the utility for taxonomic classification and the relationship of putative gene annotation and phylogeny to enzymatic function in the smallest free-living cells. Crit Rev Microbiol 1997, 23:269-354.

22. Wieles B, van Soolingen $D$, Holmgren A, Offringa R, Ottenhoff $T$, Thole J: Unique gene organization of thioredoxin and thioredoxin reductase in Mycobacterium leprae. Mol Microbiol 1995, 16:921-929.

23. Oliva G, Romero I, Ayala G, Barrios-Jacobo I, Celis H: Characterization of the inorganic pyrophosphatase from the pathogenic bacterium Helicobacter pylori. Arch Microbiol 2000, 174:104-110. 
24. Shimizu T, Imai M, Araki S, Kishida K, Terasawa Y, Hachimori A: Some properties of inorganic pyrophosphatase from Bacillus subtilis. Int $J$ Biochem Cell Biol 1997, 29:303-310.

25. Hoe HS, Kim HK, Kwon ST: Expression in Escherichia coli of the thermostable inorganic pyrophosphatase from the Aquifex aeolicus and purification and characterization of the recombinant enzyme. Protein Expr Purif 2001, 23:242-248.

26. Verhoeven JA, Schenck KM, Meyer RR, Trela JM: Purification and characterization of an inorganic pyrophosphatase from the extreme thermophile Thermus aquaticus. J Bacteriol 1986, 168:318-321.

27. Gomez-Garcia MR, Losada M, Serrano A: Comparative biochemical and functional studies of family I soluble inorganic pyrophosphatases from photosynthetic bacteria. Febs J 2007, 274:3948-3959.

28. Yang Z, Wensel TG: Molecular cloning and functional expression of CDNA encoding a mammalian inorganic pyrophosphatase. J Biol Chem 1992, 267:24641-24647.

29. Heinritzi K, Plank G, Peteranderl W, Sandner N: [The acid-base equilibrium and carbohydrate metabolism during infection with Eperythrozoon suis]. Zentralbl Veterinarmed B 1990, 37:412-417.

30. Elwell MR, Sammons ML, Liu CT, Beisel WR: Changes in blood pH in rats after infection with Streptococcus pneumoniae. Infect Immun 1975, 11:724-726.

31. Hoelzle LE, Adelt D, Hoelzle K, Heinritzi K, Wittenbrink MM: Development of a diagnostic PCR assay based on novel DNA sequences for the detection of Mycoplasma suis (Eperythrozoon suis) in porcine blood. Vet Microbiol 2003, 93:185-196.

32. Hoelzle LE, Hoelzle K, Ritzmann M, Heinritzi K, Wittenbrink MM: Mycoplasma suis antigens recognized during humoral immune response in experimentally infected pigs. Clin Vaccine Immunol 2006, 13:116-122.

33. Ritzmann M, Grimm J, Heinritzi K, Hoelzle K, Hoelzle LE: Prevalence of Mycoplasma suis in slaughter pigs, with correlation of PCR results to hematological findings. Vet Microbiol 2009, 133:84-91.

34. Hoelzle K, Doser S, Ritzmann M, Heinritzi K, Palzer A, Elicker S, Kramer M, Felder KM, Hoelzle LE: Vaccination with the Mycoplasma suis recombinant adhesion protein MSG1 elicits a strong immune response but fails to induce protection in pigs. Vaccine 2009, 27:5376-5382.

35. Saheki S, Takeda A, Shimazu T: Assay of inorganic phosphate in the mild $\mathrm{pH}$ range, suitable for measurement of glycogen phosphorylase activity. Anal Biochem 1985, 148:277-281.

doi:10.1186/1471-2180-10-194

Cite this article as: Hoelzle et al:: Inorganic pyrophosphatase in uncultivable hemotrophic mycoplasmas: identification and properties of the enzyme from Mycoplasma suis. BMC Microbiology 2010 10:194.

\section{Submit your next manuscript to BioMed Central and take full advantage of:}

- Convenient online submission

- Thorough peer review

- No space constraints or color figure charges

- Immediate publication on acceptance

- Inclusion in PubMed, CAS, Scopus and Google Scholar

- Research which is freely available for redistribution

Submit your manuscript at www.biomedcentral.com/submit
Biomed Central 